\title{
Rumen fermentation of lignocellulosic biomass from wheat straw and date leaf inoculated with bacteria isolated from termite gut
}

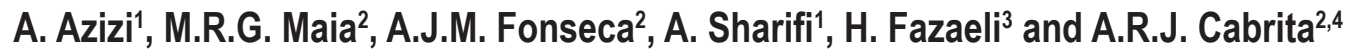 \\ ${ }^{1}$ Lorestan University, School of Agriculture, Animal Science Group, P.O. Box 465, Khoramabad, Iran \\ ${ }^{2}$ REQUIMTE, LAQV, ICBAS, Institute of Biomedical Sciences of Abel Salazar, University of Porto, \\ Jorge Viterbo Ferreira Street 228, 4050-313 Porto, Portugal \\ ${ }^{3}$ Animal Science Research Institute, P.O. Box 1483-31585, Karaj, Iran
}

KEY WORDS: inoculation, fibrous by-products, in vitro gas production, ruminants, termite gut bacteria

Received: 22 January 2018

Revised: 22 May 2018

Accepted: 14 August 2018

${ }^{4}$ Corresponding author:

e-mail: arcabrita@icbas.up.pt

\begin{abstract}
This experiment evaluated the effects of the inoculation of lignocellulosic biomass from wheat straw (LBWS) and date (Phoenix dactylifera L.) leaf (LBDL) with bacteria (Bacillus licheniformis, Ochrobactrum intermedium and Microbacterium paludicola) with lignocellulose-degrading potential isolated from termite gut on the nutritive value of these substrates. Inoculation with $B$. licheniformis and M. paludicola had a significant effect on chemical composition (organic matter, crude protein and neutral detergent fibre (NDF) contents) of LBWS whereas for LBDL bacterial treatments only tended to affect protein and NDF contents. LBWS inoculated with $B$. licheniformis and $M$. paludicola promoted a lower in vitro gas production from soluble fractions, while all bacterial treatments lowered gas production from insoluble but fermentable fractions of LBDL. Bacterial treatments differently affected the nutritive value of LBWS and LBDL - the effects were more marked for LBWS and with the inoculation with $B$. licheniformis and M. paludicola. None of the bacteria degraded lignin after three weeks of inoculation. More research is needed to evaluate longer bacterial treatments and different bacterial strains.
\end{abstract}

\section{Introduction}

Agro-industrial by-products are annually produced worldwide. Such by-products could be used in animal feeding contributing to overcome the shortage of animal feedstuffs. However, fibrous byproducts are characterized by high lignin content, low protein content, and low digestibility which, in addition to the poor palatability of lignocellulosic biomass, can limit its use as a unique ingredient in diets and its inclusion level in a complete diet. Lignin is known to reduce the digestibility of plant cell wall (Shrivastava et al., 2014). Despite the existence of physical (i.e., grinding) and chemical (i.e., soaking with sodium hydroxide or alkaline hydrogen peroxide solutions (Ghasemi et al., 2013)) methods to improve the nutritive value of fibrous by-products, research is currently focused on biological approaches, more environmentally friendly and widely acceptable (Basu et al., 2002; Kuhar et al., 2008; Neifar et al., 2013).

Organisms such as white rot fungi, some soil microbes and some insects are known to have the ability to degrade lignin (Borji, 2003). Insects such as beetles, cockroaches and termites are able to use wood as a feed source. Ability of termites to digest lignin barrier and polymer carbohydrates has been well demonstrated (Hyodo et al., 1999; Watanabe and Tokuda, 2010). In recent years increased attention has been paid to the role of bacteria in 
degrading lignin and other lignocellulosic materials. Indeed, bacteria isolated from termite gut with aromatic degrading capacity have been reported (Chung et al., 1994; Harazono et al., 2003; Bugg et al., 2011). An earlier study demonstrated that termites could degrade natural and synthetic lignin and related compounds by the action of their gut microorganisms (Butler and Buckerfield, 1979). It was found that $28 \%$ of dealkalized lignin and $60-95 \%$ of lignin dimer compounds were degraded when a culture media containing ligninic compounds was incubated with mixed bacteria isolated from the gut of termite Nasutitermes takasagoensis (Kato et al., 1998). Moreover, Borji (2003) isolated Bacillus sphaericus, Enterobacter cloacae and Ochrobactrum anthropi from the gut of termite Anacanthotermes vagans and showed their ability to grow on media containing lignin and lignocellulose as the sole source of carbon and energy.

Processing agricultural by-products with symbiotic lignocellulose-degrading bacteria from termite gut could improve their nutritive value through the degradation of lignin, a compound resistant to rumen fermentation, thus increasing plant cell wall digestibility (Salman et al., 2008; Okano et al., 2009). Information on the use of these processed by-products in ruminants is scarce, with few data available on the effects of processing on nutritive value, rumen fermentation, and overall animal. In our previous work, incubation of lignocellulosic biomass from wheat straw (LBWS) and date (Phoenix dactylifera) leaf (LBDL) for 6 weeks with lignocellulose-degrading bacteria isolated from termite gut partially changed their chemical composition, while increased nutrients digestibility (Azizi-Shotorkhoft et al., 2016). We hypothesized that decreasing the processing period from 6 to 3 weeks may have a similar outcome on nutrients digestibility, thus resulting in a more feasible process of ruminant nutrition. The fibrous by-products used to test our hypothesis were wheat straw and date leaf. Cereal straws are an important feed resource worldwide, also date palm tree production and resulting from it by-products are increasing (Chao and Krueger, 2007). In fibrous by-products, the carbohydrate accessibility constitutes a main bottleneck due to its embedment in lignin matrix. Thus, a successful treatment would be crucial to convert these lignocellulosic compounds to value-added products. Therefore, this study was carried out to investigate the chemical composition and in vitro gas production (IVGP) and fermentation parameters of LBWS and LBDL treated for 3 weeks with three different bacteria (Bacillus licheniformis,
Ochrobactrum intermedium and Microbacterium paludicola) with lignin and lignocellulose-degrading potential isolated from the gut of Microcerotermes diversus termite.

\section{Material and methods}

\section{Lignocellulolytic bacteria isolation}

Three bacteria (B. licheniformis, $O$. intermedium and M. paludicola) were isolated from the gut of the termite $M$. diversus as described by Azizi-Shotorkhoft et al. (2016). These isolates were grown on different culture media (terrific buffer, Siu (1951); and sterile basal media, Cartwright and Holdom (1973). The isolates were screened based on lignin peroxidase activity and identified using 16S rRNA sequence analysis (Azizi-Shotorkhoft et al., 2016), and maintained in nutrient broth (Fahy and Persley, 1983).

\section{Inoculation of substrate lignocellulosic biomass with isolated bacteria}

Wheat straw and date leaf samples were ground in a hammer mill with a 1-mm screen (Arthur Hill Thomas Co., Philadelphia, PA, USA), and extracted with boiling water for $1 \mathrm{~h}$ (4 changes of water during extraction) to separate lignocellulose from water-soluble carbohydrate and protein fractions. Lignocellulosic biomass was dried for $48 \mathrm{~h}$ at $60^{\circ} \mathrm{C}$ and incubated with lignocellulose degrading bacteria in 11-Erlenmeyer flasks with M9 medium (Kato et al., 1998). After sterilization, each flask was inoculated with $3 \mathrm{ml}$ of each bacterial culture, grown for $48 \mathrm{~h}$, and maintained in a shaking incubator for 3 weeks at $37^{\circ} \mathrm{C}$ under aerobic conditions. Equally managed flasks with substrates but without added bacteria were also incubated and served as controls. A total of 16 flasks were prepared ( 2 substrates $\times 4$ treatments, 2 replicates in each treatment).

At the end of the incubation period, contents of each flask were filtered and the residue was collected and dried for $48 \mathrm{~h}$ at $60{ }^{\circ} \mathrm{C}$. Dry matter (DM) loss of each treatment during incubation was calculated from the difference between the weight of the sample before and after incubation. Obtained residues were incubated with rumen inocula in short term in vitro trials to evaluate effects of biological treatments of LBWS and LBDL on rumen fermentation parameters.

\section{Rumen contents collection}

Rumen inocula were obtained from adult, dry and not pregnant Holstein cows fitted with a rumen cannula (10 cm diameter; Bar Diamond Inc., Parma, 
ID, USA). Cows were housed at the Agricultural Campus of Abel Salazar Biomedical Sciences Institute, University of Porto (ICBAS-UP, Vairão, Vila do Conde, Portugal) and were handled in strict accordance with good animal practice (European Union Directive 2010/63/EU). Experimental animal procedures were previously approved, licensed and conducted by trained scientists, as described by Maia et al. (2016).

Two cows were fed two different total mixed rations for two-week adaptation period to achieve true replicates. After rumen inocula collection, diets were swapped between cows. Two total mixed rations were based either on wheat straw or hay silage and contained in $1 \mathrm{~kg}$ of DM: $141 \mathrm{~g}$ crude protein (CP) and $598 \mathrm{~g}$ neutral detergent fibre (NDF), and $117 \mathrm{~g} \mathrm{CP}$ and $659 \mathrm{~g}$ NDF, respectively. Cows were fed twice a day, at 9:00 and 17:00, the daily amount of feed equally offered at both meals, and had continuous access to fresh drinking water. After the two-week adaptation period to the diet, rumen contents were collected from all quadrants of the rumen of each cow and placed in a pre-warmed $\left(39^{\circ} \mathrm{C}\right)$ thermal container. Rumen contents were transported to the laboratory, individually homogenized and strained through 4 layers of linen cloth under $\mathrm{O}_{2}$-free $\mathrm{CO}_{2}$. The length of time between collection of rumen contents and incubation never exceeded $60 \mathrm{~min}$.

\section{Rumen in vitro incubations}

For each substrate (i.e., LBWS or LBDL) a total of 40 bottles [ 4 treatments (no added bacteria, and treated with $B$. licheniformis, $O$. intermedium and M. paludicola) $\times 2$ inocula (from cows fed a total mixed ration based on wheat straw or hay silage) $\times$ 2 replicates (two flasks per treatment) $\times 2$ periods (each cow was fed two total mixed rations in two periods) $=32$ and blanks (i.e., rumen fluid only) in duplicate per donor and per period $(2$ replicates $\times$ 2 donor $\times 2$ period $=8$ bottles)], were incubated; 20 bottles for IVGP and another 20 for fermentation parameters estimation. Kinetics of in vitro gas production was measured as described by Marten and Barnes (1980) for $144 \mathrm{~h}$ due to the high fibre content of the substrates used. Approximately $250 \mathrm{mg}$ sample, DM basis (with particle size of $1 \mathrm{~mm}$ ), were accurately weighed into $125 \mathrm{ml}$-serum bottles. Each bottle was filled with $5 \mathrm{ml}$ strained rumen fluid and $20 \mathrm{ml}$ Marten and Barnes (1980) buffer solution, and immediately flushed with $\mathrm{O}_{2}$-free $\mathrm{CO}_{2}$, closed with a butyl rubber stopper, sealed with aluminium crimp, shaken and placed in a water-bath at $39^{\circ} \mathrm{C}$. Volume of gas produced was recorded at 3, 6, 8, 12, 16, 24, 48, 72, 96, 120 and
$144 \mathrm{~h}$ using a digital pressure transducer (Tracker 200, Baley and Mackey, Ltd., Birmingham, UK) (Theodorou et al., 1994).

Fermentation parameters were determined after $48 \mathrm{~h}$ of incubation. Bottles were placed in an icebath to stop fermentation, and gradually warmed up to $25^{\circ} \mathrm{C}$. The volume of gas produced was recorded, and bottles were uncapped for immediate measurement of pH (GLP22+ pH meter; Crison Instruments SA, Barcelona, Spain). Samples of supernatant $(5 \mathrm{ml})$ from each bottle were immediately preserved with $5 \mathrm{ml}$ of $\mathrm{HCl} 0.1 \mathrm{~N}$ and stored at $-20{ }^{\circ} \mathrm{C}$ for ammonia nitrogen analysis (\#954.01; AOAC International, 1995). For determination of volatile fatty acids (VFA), $1.0 \mathrm{ml}$ of supernatant was added to $0.25 \mathrm{ml} 25 \%$ orthophosphoric acid solution with $16 \mathrm{mM}$ 3-methyl-valeric acid (internal standard; Sigma-Aldrich Inc., St. Louis, MO, USA) and stored at $-20{ }^{\circ} \mathrm{C}$. Ammonia nitrogen was determined by steam distillation and VFA by gas liquid chromatography as described by Maia et al. (2016). Fermentation residues were oven-dried at $60{ }^{\circ} \mathrm{C}$ for $48 \mathrm{~h}$ for estimation of DM disappearance (DMD).

\section{Calculations}

The exponential equation of Ørskov and McDonald (1979) was used to estimate the kinetic parameters throughout the in vitro fermentation:

$$
\mathrm{Y}=\mathrm{a}+\mathrm{b}\left(1-\mathrm{e}^{-\mathrm{ct}}\right)
$$

where: $Y$ - volume of gas produced at time t; $\mathrm{a}$ - gas produced from soluble fractions $(\mathrm{ml}) ; \mathrm{b}-$ gas produced from insoluble but fermentable fractions [the asymptotic gas production $(\mathrm{ml})$ ]; $\mathrm{c}$ - rate of gas production $\left(\mathrm{h}^{-1}\right)$, and $\mathrm{t}$ - incubation time $(\mathrm{h})$.

The DM and neutral detergent fibre (NDF) disappearance (\%) at $48 \mathrm{~h}$ of incubation were calculated as the difference between their content in the sample before incubation and their amounts in the residue after ruminal incubation.

\section{Chemical analyses}

Samples of LBWS and LBDL were analysed for DM (\#930.15), ash (\#924.05) and N (\#954.01) using standard methods as described in AOAC International (1995). The NDF (inclusive of residual ash) was measured without the use of sodium sulphite or amylase according to Van Soest et al. (1991). Acid detergent fibre (ADF; \#973.18) was determined and expressed inclusive of residual ash (AOAC International, 1995). Acid detergent lignin (ADL) was determined using the sulphuric acid method and expressed inclusive of residual ash (Robertson and Van Soest, 1981). 


\section{Statistical analysis}

For each substrate (LBWS or LBDL), all parameters (including IVGP, fermentation parameters and nutrient disappearance) were analysed using the GLM procedure of $\mathrm{SAS}^{\circledR}$ software (SAS Institute Inc., Cary, NC, USA), according to the model:

$$
\mathrm{Y}_{\mathrm{ij}}=\mu+\mathrm{T}_{\mathrm{i}}+\mathrm{e}_{\mathrm{ij}}
$$

where: $Y_{i j}-$ measured value, $\mu$ - general mean, $\mathrm{T}_{\mathrm{i}}-$ effect of isolated bacteria on investigated parameters, and $\mathrm{e}_{\mathrm{ij}}$ - residual error. Means were compared by the Duncan multiple comparison test. Significance was declared at $P<0.05$.

\section{Results}

\section{Chemical composition}

As shown in Tables 1 and 2, bacterial treatments increased $(P<0.05)$ weight loss of both LBWS and LBDL in comparison to control. For LBWS, the highest weight loss was observed with B. licheniformis, but not differing from M. paludicola. All treatments similarly increased weight loss of LBDL.

The OM content decreased with the inoculation of LBWS with B. licheniformis and M. paludicola. Crude protein content only decreased after inoculation of LBWS with $B$. licheniformis while all treatments decreased NDF content. Acid detergent content tended to be lower $(P=0.087)$ in LBWS inoculated with $M$. paludicola, while ADL content remained unchanged. Bacterial treatments of LBDL tended to decrease CP $(P=0.086)$ and NDF $(P=0.059)$ contents, whereas $B$. licheniformis and $M$. paludicola inoculation decreased ADF content $(P<0.02)$, and ADL content remained unchanged.

Table 1. Weight loss and chemical composition of lignocellulosic biomass from wheat straw not inoculated (control) and inoculated with three bacteria isolated from termite gut

\begin{tabular}{|c|c|c|c|c|c|c|}
\hline \multirow{2}{*}{ Indices, \% DM } & \multicolumn{4}{|c|}{ Biological treatments } & \multirow{2}{*}{ SEM } & \multirow{2}{*}{$P$-value } \\
\hline & control & $\mathrm{BL}$ & MP & Ol & & \\
\hline Weight loss (DM) & $3.67^{\circ}$ & $9.67^{a}$ & $7.45^{\mathrm{ab}}$ & $6.67^{b}$ & 0.701 & 0.017 \\
\hline $\mathrm{OM}$ & $93.0^{\mathrm{a}}$ & $92.2^{b}$ & $91.8^{b}$ & $93.0^{\mathrm{a}}$ & 0.12 & 0.004 \\
\hline $\mathrm{CP}(\mathrm{N} \times 6.25)$ & $4.52^{\mathrm{a}}$ & $2.48^{b}$ & $5.97^{a}$ & $5.89^{a}$ & 0.427 & 0.013 \\
\hline NDF & $93.7^{\mathrm{a}}$ & $89.0^{c}$ & $89.6^{b c}$ & $90.6^{b}$ & 0.27 & 0.001 \\
\hline ADF & 61.7 & 61.5 & 60.8 & 61.2 & 0.19 & 0.087 \\
\hline ADL & 13.1 & 12.1 & 12.0 & 13.0 & 0.55 & 0.417 \\
\hline
\end{tabular}

BL - Bacillus licheniformis; MP - Microbacterium paludicola; $\mathrm{OI}$ - Ochrobactrum intermedium; DM - dry matter; OM - organic matter; CP - crude protein; NDF - neutral detergent fibre (with residual ash); ADF - acid detergent fibre; ADL - acid detergent lignin; SEM standard error of means; ${ }^{a b c}$ - means within a row with different superscripts are significantly different at $P<0.05$
Table 2. Weight loss and chemical composition of lignocellulosic biomass from date leaf not inoculated (control) and inoculated with three bacteria isolated from termite gut

\begin{tabular}{lcccclll}
\hline \multirow{2}{*}{ Indices, \% DM } & \multicolumn{9}{c}{ Biological treatments } & \multirow{2}{*}{ SEM } & $P$-value \\
\cline { 2 - 5 } & control & $\mathrm{BL}$ & $\mathrm{MP}$ & $\mathrm{OI}$ & & \\
\hline Weight loss (DM) & $2.44^{\mathrm{b}}$ & $7.67^{\mathrm{a}}$ & $6.45^{\mathrm{a}}$ & $5.78^{\mathrm{a}}$ & 0.601 & 0.014 \\
$\mathrm{OM}$ & 88.7 & 87.9 & 88.8 & 88.3 & 0.23 & 0.148 \\
$\mathrm{CP}(\mathrm{N} \times 6.25)$ & 5.51 & 5.62 & 6.88 & 8.13 & 0.570 & 0.086 \\
$\mathrm{NDF}$ & 93.4 & 90.8 & 89.2 & 90.9 & 0.70 & 0.059 \\
$\mathrm{ADF}$ & $74.4^{\mathrm{a}}$ & $73.7^{\mathrm{b}}$ & $73.9^{\mathrm{b}}$ & $74.3^{\mathrm{a}}$ & 0.10 & 0.020 \\
$\mathrm{ADL}$ & 28.6 & 28.4 & 29.0 & 28.7 & 0.68 & 0.939 \\
\hline
\end{tabular}

BL - Bacillus licheniformis; MP - Microbacterium paludicola; $\mathrm{OI}$ - Ochrobactrum intermedium; DM - dry matter; OM - organic matter; $\mathrm{CP}$ - crude protein; NDF - neutral detergent fibre (with residual ash); ADF - acid detergent fibre; ADL - acid detergent lignin; SEM standard error of means; ${ }^{\text {abc }}$ - means within a row with different superscripts are significantly different at $P<0.05$

\section{In vitro gas production, nutrient disappearance and fermentation parameters}

After $144 \mathrm{~h}$ incubation, gas production from soluble fractions (parameter from the model of Ørskov and McDonald, 1979) of LBWS was the highest for control $(P<0.05)$, but not different from LBWS inoculated with $O$. intermedium (Table 3).

Table 3. In vitro fermentation parameters of lignocellulosic biomass from wheat straw not inoculated (control) and inoculated with different bacteria isolated from termite gut

\begin{tabular}{lcccclll}
\hline \multirow{2}{*}{ Indices } & \multicolumn{3}{l}{ Biological treatments } & \multirow{2}{*}{ SEM } & P-value \\
\cline { 2 - 5 } & control & BL & MP & Ol & & \\
\hline IVGP & 56.2 & 56.5 & 55.4 & 56.4 & 1.19 & 0.911 \\
a & $3.74^{\mathrm{a}}$ & $1.85^{\mathrm{b}}$ & $2.30^{\mathrm{b}}$ & $3.10^{\mathrm{ab}}$ & 0.462 & 0.034 \\
$\mathrm{~b}$ & 51.9 & 53.7 & 52.5 & 52.7 & 1.32 & 0.801 \\
$\mathrm{a}+\mathrm{b}$ & 55.7 & 55.6 & 54.8 & 55.8 & 1.29 & 0.948 \\
$\mathrm{c}$ & 0.032 & 0.039 & 0.036 & 0.032 & 0.0029 & 0.209 \\
$\mathrm{DMD}$ & 32.4 & 34.5 & 34.3 & 35.7 & 1.27 & 0.349 \\
$\mathrm{OMD}$ & 33.1 & 34.5 & 35.0 & 34.2 & 0.70 & 0.486 \\
$\mathrm{NDFD}$ & 35.9 & 35.1 & 35.7 & 34.6 & 1.69 & 0.934 \\
$\mathrm{ME}$ & 4.87 & 5.11 & 5.13 & 5.03 & 0.133 & 0.530 \\
$\mathrm{pH}$ & 6.13 & 6.08 & 6.12 & 6.13 & 0.021 & 0.391 \\
$\mathrm{NH}{ }_{3}-\mathrm{N}$ & $21.1^{\mathrm{b}}$ & $18.5^{\mathrm{b}}$ & $30.3^{\mathrm{a}}$ & $15.8^{\mathrm{b}}$ & 2.15 & 0.001 \\
\hline
\end{tabular}

$\mathrm{BL}$ - Bacillus licheniformis; MP - Microbacterium paludicola; OI - Ochrobactrum intermedium; IVGP - in vitro gas production after $144 \mathrm{~h}$ of incubation (ml); $\mathrm{a}-$ the gas production from soluble fractions after $144 \mathrm{~h}(\mathrm{ml}) ; \mathrm{b}$ - the gas production from insoluble but fermentable fractions after $144 \mathrm{~h}(\mathrm{ml}) ; \mathrm{a}+\mathrm{b}-$ potential of degradability of the material after $144 \mathrm{~h}$ incubation (ml); $\mathrm{c}$ - rate constant of gas production during incubation (/h); DMD - dry matter (DM) disappearance (\%); OMD - organic matter (OM) disappearance (\%); NDFD - neutral detergent fibre disappearance (\%); ME - estimated metabolizable energy (MJ/kg DM); $\mathrm{NH}_{3}-\mathrm{N}$ - ammonia nitrogen (mg/dl); SEM - standard error of means; ${ }^{a b}$ - means within a row with different superscripts are significantly different at $P<0.05$ 
Table 4. In vitro fermentation parameters of lignocellulosic biomass from date leaf not inoculated (control) and inoculated with different bacteria isolated from termite gut

\begin{tabular}{|c|c|c|c|c|c|c|}
\hline \multirow{2}{*}{ Indices } & \multicolumn{4}{|c|}{ Biological treatments } & \multirow{2}{*}{ SEM } & \multirow{2}{*}{$P$-value } \\
\hline & control & $\mathrm{BL}$ & MP & Ol & & \\
\hline IVGP & 44.5 & 42.0 & 42.5 & 42.3 & 0.89 & 0.216 \\
\hline a & 4.14 & 4.77 & 4.70 & 4.23 & 0.373 & 0.533 \\
\hline b & $39.2^{\mathrm{a}}$ & $35.9^{b}$ & $36.9^{b}$ & $37.1^{\mathrm{b}}$ & 0.68 & 0.015 \\
\hline$a+b$ & 43.4 & 40.7 & 41.6 & 41.3 & 0.78 & 0.117 \\
\hline c & 0.039 & 0.038 & 0.032 & 0.034 & 0.0055 & 0.804 \\
\hline DMD & 19.6 & 18.5 & 17.1 & 16.1 & 1.17 & 0.184 \\
\hline OMD & 27.3 & 25.4 & 26.2 & 26.9 & 0.57 & 0.084 \\
\hline NDFD & $22.4^{\mathrm{a}}$ & $16.9^{b}$ & $14.3^{\mathrm{b}}$ & $16.7^{\mathrm{b}}$ & 1.40 & 0.003 \\
\hline $\mathrm{ME}$ & 3.93 & 3.62 & 3.73 & 3.84 & 0.086 & 0.083 \\
\hline $\mathrm{pH}$ & 6.30 & 6.31 & 6.32 & 6.32 & 0.021 & 0.941 \\
\hline $\mathrm{NH}_{3}-\mathrm{N}$ & 15.1 & 16.9 & 18.8 & 18.9 & 2.14 & 0.571 \\
\hline
\end{tabular}

BL - Bacillus licheniformis; MP - Microbacterium paludicola; OI - Ochrobactrum intermedium; IVGP - in vitro gas production after $144 \mathrm{~h}$ of incubation (ml); a - the gas production from soluble fractions after $144 \mathrm{~h}(\mathrm{ml}) ; \mathrm{b}$ - the gas production from insoluble but fermentable fractions after $144 \mathrm{~h}(\mathrm{ml}) ; \mathrm{a}+\mathrm{b}$ - potential of degradability of the material after $144 \mathrm{~h}$ incubation (ml); $\mathrm{c}$ - rate constant of gas production during incubation (/h); DMD - dry matter (DM) disappearance (\%); $\mathrm{OMD}$ - organic matter (OM) disappearance (\%); NDFD - neutral detergent fibre disappearance (\%); ME - estimated metabolizable energy (MJ/kg DM); $\mathrm{NH}_{3}-\mathrm{N}$ - ammonia nitrogen ( $\mathrm{mg} / \mathrm{dl}$ ); SEM - standard error of means; ab - means within a row with different superscripts are significantly different at $P<0.05$

For LBDL, the highest $(P<0.05$, Table 4$)$ gas production from insoluble but fermentable fractions (i.e., b) was observed in the control group. Other IVGP characteristics were unaffected $(P>0.05)$ by bacterial treatment in both substrates. For LBWS (Table 3), except for ammonia nitrogen concentration which was the highest $(P<0.01)$ in M. paludicola inoculated LBWS, fermentation parameters such as disappearance of DM (DMD), OM (OMD) and NDF (NDFD), estimated $\mathrm{ME}$ and $\mathrm{pH}$ were

Table 5. Volatile fatty acid (VFA) production of lignocellulosic biomass from wheat straw not inoculated (control) and inoculated with different bacteria isolated from termite gut

\begin{tabular}{lccccccc}
\hline \multirow{2}{*}{ Indices } & \multicolumn{9}{c}{ Biological treatments } & \multirow{2}{*}{ SEM } & $P$-value \\
\cline { 2 - 5 } & control & $\mathrm{BL}$ & $\mathrm{MP}$ & $\mathrm{OI}$ & & \\
\hline VFA, mmol/l & & & & & & \\
$\quad$ total VFA & 23.8 & 25.7 & 24.1 & 24.1 & 0.78 & 0.343 \\
acetate (A) & 15.9 & 16.9 & 15.8 & 15.8 & 0.55 & 0.453 \\
propionate (P) & 4.76 & 5.28 & 4.96 & 5.02 & 0.301 & 0.688 \\
butyrate & 2.01 & 2.20 & 2.08 & 2.07 & 0.128 & 0.783 \\
isobutyrate & 0.33 & 0.37 & 0.34 & 0.35 & 0.011 & 0.221 \\
valerate & 0.25 & 0.27 & 0.26 & 0.26 & 0.013 & 0.821 \\
isovalerate & 0.56 & 0.63 & 0.58 & 0.59 & 0.029 & 0.426 \\
$\quad$ caproate & 0.03 & 0.04 & 0.04 & 0.03 & 0.008 & 0.889 \\
A:P & 3.39 & 3.26 & 3.26 & 3.22 & 0.183 & 0.913 \\
\hline
\end{tabular}

BL - Bacillus licheniformis; MP - Microbacterium paludicola; $\mathrm{OI}$ - Ochrobactrum intermedium; SEM - standard error of means unaffected $(P>0.05)$ by the treatment. For LBDL (Table 4), OMD and estimated ME tended to decrease $(P<0.09)$ and NDFD decreased $(P<0.01)$ with bacterial treatment, the other fermentation parameters were unchanged $(P>0.05)$.

Bacterial treatment of LBWS had no effect on total VFA production and individual VFA concentrations after $48 \mathrm{~h}$ in vitro incubation (Table 5). For LBDL, propionate concentration tended $(P=0.056)$ to decrease with $M$. paludicola treatment in comparison to control, and isobutyrate concentration $(P=0.042)$ was the lowest with $M$. paludicola treatment (Table 6).

Table 6. Volatile fatty acid (VFA) production of lignocellulosic biomass from date leaf not inoculated (control) and inoculated with different bacteria isolated from termite gut

\begin{tabular}{llllllll}
\hline \multirow{2}{*}{ Indices } & \multicolumn{3}{c}{ Biological treatments } & \multirow{2}{*}{ SEM } & \multirow{2}{*}{$P$-value } \\
\cline { 2 - 5 } & control & $\mathrm{BL}$ & $\mathrm{MP}$ & $\mathrm{OI}$ & & \\
\hline VFA, mmol/L & & & & & & \\
$\quad$ total VFA & 19.5 & 18.6 & 17.1 & 18.9 & 0.75 & 0.152 \\
acetate $(\mathrm{A})$ & 12.9 & 12.5 & 11.6 & 12.7 & 0.57 & 0.370 \\
propionate $(\mathrm{P})$ & 3.90 & 3.50 & 3.19 & 3.56 & 0.171 & 0.056 \\
butyrate & 1.44 & 1.34 & 1.21 & 1.36 & 0.112 & 0.558 \\
isobutyrate & $0.36^{\mathrm{a}}$ & $0.34^{\mathrm{a}}$ & $0.31^{\mathrm{b}}$ & $0.35^{\mathrm{a}}$ & 0.012 & 0.042 \\
valerate & 0.25 & 0.24 & 0.22 & 0.25 & 0.015 & 0.367 \\
isovalerate & 0.65 & 0.63 & 0.55 & 0.62 & 0.031 & 0.154 \\
$\quad$ caproate & 0.035 & 0.038 & 0.032 & 0.038 & 0.0073 & 0.933 \\
A:P & 3.32 & 3.61 & 3.67 & 3.59 & 0.165 & 0.465 \\
\hline
\end{tabular}

BL - Bacillus licheniformis; MP - Microbacterium paludicola; OI - Ochrobactrum intermedium; SEM - standard error of means

\section{Discussion}

Chemical composition. The observed DM loss for both substrates after 3 weeks of incubation suggests the occurrence of bacterial growth. The results are consistent with those obtained by Borji (2003) with LBWS inoculated with three bacteria (Bacillus sp., Enterobacter sp. and Ochrobacterium sp.) isolated from the gut of termite Anacanthotermes vagans over 3, 6 or 9 weeks. The higher weight loss after 3 weeks of incubation observed by Borji (2003) than in the present study probably reflects the different degradation abilities of the organisms used. Additionally, in a previous study (Azizi-Shotorkhoft et al., 2016), the DM loss of LBWS and LBDL increased by bacterial inoculation after 6 weeks, with the highest values observed with $B$. licheniformis inoculation. In the current work, average DM loss of LBWS and LBDL by bacterial inoculation were respectively 7.93 and $6.63 \%$, while in our previous study (Azizi-Shotorkhoft et al., 2016) these amounts were 
higher (10.7 and 8.78\% for LBWS and LBDL, respectively), most probably due to the different incubation times of substrates (i.e., 3 vs 6 weeks). Moreover, the higher weight loss observed with LBWS than with LBDL could reflect the higher carbohydrate and lower ADL content in LBWS (Azizi-Shotorkhoft et al., 2016). Reduction of OM content in LBWS with bacteria inoculation in comparison to LBDL was probably due to lower lignin content in LBWS. It has been shown that high lignin content reduces access to other cell wall contents of fibrous by-products such as cellulose and hemicellulose (Borji, 2003). Presence of phenolic materials in LBDL that could interfere with substrate availability and microbial degradation could have also contributed to unchanged OM content by experimental isolates.

In the present study, results concerning chemical composition of both substrates differ from those of our previous work (Azizi-Shotorkhoft et al., 2016) using the same bacteria, but with different incubation times. Indeed, in the previous study, OM and NDF contents of LBWS and LBDL were unchanged by treatments, ADL and CP in LBWS, respectively, decreased and increased with $M$. paludicola inoculation as compared to the control, while for LBDL, ADL contents were unaffected and ADF content decreased under treatments.

The effect of bacteria isolated from the termite gut ecosystem on the chemical composition of lignocellulose biomass used as ruminant feed is not comprehensively described in the literature. It is known that in the world exist more than 2700 termite species (Culliney and Grace, 2000) with different types of gut microbes, and only few studies have been conducted on the treatment of lignocellulosic by-products by ligninolytic bacteria isolated from such ecosystem. In an earlier study by Crawford (1978) it was observed that Streptomyces strains degraded $25-40 \%$ of cellulose content of lignocellulose prepared from Douglas fir (Pseudotsuga menziesii) after 6 weeks of incubation. Similarly, Crawford et al. (1983) refered a $44 \%$ decrease of carbohydrate content of maize stem after 8 weeks of incubation with Streptomyces viridosporus isolated from the soil and Kerr and Kerr (1987) found a $6.5 \%$ degradation of grass polysaccharides after 10-day incubation with Arthrobacter isolated from environmental sources. Conversely to our results, Borji (2003) observed no differences in NDF content of LBWS after its incubation with isolated bacteria from termite gut over 4 weeks.
In vitro gas production, nutrient disappearance and fermentation parameters. It is worth noting that bacterial inoculation had only minor effects on the chemical composition of substrates, nevertheless it decreased (or tended to decrease) NDF $(P<0.05)$, and $\mathrm{OM}$ digestibilities $(P=0.084)$ and metabolizable energy content $(P=0.083)$ in LBDL, although no effects were observed in LBWS. Reduction of nutrient disappearance in LBDL samples treated with termite gut bacteria might be related to interference of its phenolic compounds with substrate availability and microbial degradation (McSweeney et al., 2001).

The increased ammonia nitrogen concentration in M. paludicola-treated LBWS in line with its higher $\mathrm{CP}$ content and, along with the highest DM losses, could suggest that this biological treatment promoted a higher fermentation of LBWS, however this was not reflected in nutrient disappearance. To improve the access of rumen microbial enzymes to lignocellulosic material, thus enhancing digestibility, the breakdown of lignin-carbohydrate linkages in plant cell walls is essential (Shrivastava et al., 2012). It should be stated that in the present study the lignocellulose-degrading bacteria treatment lasted 3 weeks, which could have been insufficient to efficiently break the lignin-carbohydrate linkages of LBWS and LBDL. Indeed, Azizi-Shotorkhoft et al. (2016) incubated LBWS and LBDL with the same bacteria isolates for 6 weeks and found an improved in vitro DM and OM digestibility in both substrates, although the impact on their chemical composition was small. Borji (2003) investigated the digestibility of LBWS inoculated with different bacteria (Bacillus sp., Enterobacter sp. and Ochrobacterium sp.) isolated from termite gut during 3, 6 and 9 weeks and, conversely to our results, DM digestibility was improved in all incubation times, the digestibility of LBWS have increased in line with length of incubation (average DM digestibility improved $43.0,48.4$ and $50.7 \%$ respectively for 3, 6, and 9 weeks of incubation). It should be noted that besides the duration of the processing period, the type of by-product, physical or chemical pre-treatment and growth promoters (i.e., different readily fermentable carbohydrates and nitrogen sources) could also affect the nutritive value of agricultural by-products processed with termite gut bacteria (Borji, 2003).

\section{Conclusions}

Wheat straw and date leaf are by-products markedly available worldwide, but the high content of lignin constitutes a main bottleneck for their use in 
animal feeding. In the present study, lignocellulosic biomass from wheat straw (LBWS) and date (Phoenix dactylifera) leaf (LBDL) were inoculated with lignocellulose-degrading bacteria (Bacillus licheniformis, Ochrobactrum intermedium and Microbacterium paludicola) isolated from termite gut during 3 weeks to convert these lignocellulosic compounds to value-added products. Effects were different among substrates and bacterial isolates used. None of the bacteria were able to degrade lignin after 3 weeks inoculation. More research is needed regarding the isolation of organisms with higher lignin and lignocellulose-degrading potential from termite gut ecosystem for biological treatment of agricultural by-products and improvement of their nutritive value.

\section{Acknowledgments}

The authors are grateful for financial support from the European Union (FEDER funds through COMPETE) and National Funds (Fundação para a Ciência e a Tecnologia, FCT) through project UID/ QUI/50006/2013 - POCI/01/0145/FEDER/007265 (LAQV). MRGM also acknowledge FCT for the post-doctoral grant (SFRH/BPD/70176/2010). The authors thank Sílvia Azevedo (ICBAS-UP) for the valuable technical assistance, and Cláudio Azevedo and Pedro Maia for assistance with animal care.

\section{References}

AOAC International, 1995. Official Methods of Analysis of AOAC International. $16^{\text {th }}$ Edition. Arlington, VA (USA)

Azizi-Shotorkhoft A., Mohammadabadi T., Motamedi H., Chaji M., Fazaeli H., 2016. Isolation and identification of termite gut symbiotic bacteria with lignocellulose-degrading potential, and their effects on the nutritive value for ruminants of some by-products. Anim. Feed Sci. Technol. 221, 234-242, https:// doi.org/10.1016/j.anifeedsci.2016.04.016

Basu S., Gaur R., Gomes J., Sreekrishnan T.R., Bisaria V.S., 2002. Effect of seed culture on solid-state bioconversion of wheat straw by Phanerochaete chrysosporium for animal feed production. J. Biosci. Bioeng. 93, 25-30, https://doi.org/10.1016/ S1389-1723(02)80049-4

Borji M., 2003. The survey possibility of straw polysaccharides and lignin degradation by isolated microbiota from termites. $\mathrm{PhD}$ Thesis. Tarbiat Modares University, Tehran (Iran)

Bugg T.D.H., Ahmad M., Hardiman E.M., Singh R., 2011. The emerging role for bacteria in lignin degradation and bio-product formation. Curr. Opin. Biotechnol. 22, 394-400, https://doi. org/10.1016/j.copbio.2010.10.009

Butler J.H., Buckerfield J.C., 1979. Digestion of lignin by termites. Soil Biol. Biochem. 11, 507-511, https://doi.org/10.1016/00380717(79)90010-5
Cartwright N.J., Holdom K.S., 1973. Enzymatic lignin, its release and utilization by bacteria. Microbios 8, 7-14

Chao C.T., Krueger R.R., 2007. The date palm (Phoenix dactylifera L.): overview of biology, uses, and cultivation. HortScience 42, 1077-1082

Chung S.-Y., Maeda M., Song E., Horikoshij K., Kudo T., 1994. A Grampositive polychlorinated biphenyl-degrading bacterium, Rhodococcus erythropolis strain TA421, isolated from a termite ecosystem. Biosci. Biotechnol. Biochem. 58, 2111-2113, https://doi.org/10.1271/bbb.58.2111

Crawford D.L., 1978. Lignocellulose decomposition by selected streptomyces strains. Appl. Environ. Microbiol. 35, 1041-1045

Crawford D.L., Pometto A.L., Crawford R.L., 1983. Lignin degradation by Streptomyces viridosporus: Isolation and characterization of a new polymeric lignin degradation intermediate. Appl. Environ. Microbiol. 45, 898-904

Culliney T.W., Grace J.K., 2000. Prospects for the biological control of subterranean termites (Isoptera: Rhinotermitidae), with special reference to Coptotermes formosanus. Bull. Entomol. Res. 90, 9-21, https://doi.org/10.1017/S0007485300000663

Fahy P.C., Persley G.J., 1983. Plant Bacterial Diseases: A Diagnostic Guide. Academic Press. Sydney (Australia)

Ghasemi E., Khorvash M., Ghorbani G.R., Emami M.R., Karimi K., 2013. Dry chemical processing and ensiling of rice straw to improve its quality for use as ruminant feed. Trop. Anim. Health Prod. 45, 1215-1221, https://doi.org/10.1007/s11250-012-0349-0

Harazono K., Yamashita N., Shinzato N., Watanabe Y., Fukatsu T., Kurane R., 2003. Isolation and characterization of aromatic degrading microorganisms from the gut of the lower termite Coptotermes formosanus. Biosci. Biotechnol. Biochem. 67, 889-892, https://doi.org/10.1271/bbb.67.889

Hyodo F., Azuma J.-i., Abe T., 1999. Estimation of effect of passage through the gut of a lower termite Coptotermes formosanus Shiraki, on lignin by solid-state CP/MASS ${ }^{13} \mathrm{C}$ NMR. Holzforschung 53, 244-246, https://doi.org/10.1515/HF.1999.041

Kato K., Kozaki S., Sakurananga M., 1998. Degradation of lignin compounds by bacteria from termite guts. Biotechnol. Lett. 20, 459-462, https://doi.org/10.1023/A:1005432027603

Kerr T.J., Kerr R.D., 1987. Microorganism having characteristics of an Arthrobacter capable of degrading peanut hull lignin. United State Patent No. 4643899 (USA)

Kuhar S., Nair L.M., Kuhad R.C., 2008. Pretreatment of lignocellulosic material with fungi capable of higher lignin degradation and lower carbohydrate degradation improves substrate acid hydrolysis and the eventual conversion to ethanol. Can. J. Microbiol. 54, 305-313, https://doi.org/10.1139/W08-003

Maia M.R.G., Fonseca A.J.M., Oliveira H.M., Mendonça C., Cabrita A.R.J., 2016. The potential role of seaweeds in the natural manipulation of rumen fermentation and methane production. Sci. Rep. 6, 32321, https://doi.org/10.1038/srep32321

Marten G.C., Barnes R.F., 1980. Prediction of energy digestibility of forages with in vitro rumen fermentation and fungal enzyme systems. In: W.J. Pigden, C.C. Balch, M. Graham (Editors). Standardization of Analytical Methodology for Feeds. International Development Research Centre. Ottawa (Canada), pp. 61-71

McSweeney C.S., Palmer B., Bunch R., Krause D.O., 2001. Effect of tropical forage calliandra on microbial protein synthesis and ecology in the rumen. J. Appl. Microbiol. 90, 78-88, https:// doi.org/10.1046/j.1365-2672.2001.01220.x

Neifar M., Jaouani A., Ayari A., Abid O., Salem H.B., Boudabous A., Najar T., Ghorbel R.E., 2013. Improving the nutritive value of Olive Cake by solid state cultivation of the medicinal mushroom Fomes fomentarius. Chemosphere 91, 110-114, https:// doi.org/10.1016/j.chemosphere.2012.12.015 
Okano K., Ohkoshi N., Nishiyama A., Usagawa T., Kitagawa M., 2009. Improving the nutritive value of madake bamboo, Phyllostachys bambusoides, for ruminants by culturing with the white-rot fungus Ceriporiopsis subvermispora. Anim. Feed Sci. Technol. 152, 278-285. https://doi.org/10.1016/j.anifeedsci.2009.04.021

Ørskov E.R., McDonald I., 1979. The estimation of protein degradability in the rumen from incubation measurements weighed according to rate of passage. J. Agric. Sci. 92, 499-503, https:// doi.org/10.1017/S0021859600063048

Robertson J.B., Van Soest P.J., 1981. The detergent system of analysis and its application to human foods. In: W.P.T. James 0 . Theander (Editors). The Analysis of Dietary Fibre in Food. Marcel Dekker. New York, NY (USA), pp. 123-158

Salman F.M., El-Kadi R.I., Abdel-Rahman H., Ahmed S.M., Mohamed M.I., Shoukry M.M., 2008. Biologically treated sugar beet pulp as a supplement in goat rations. Int. J. Agric. Biol. 10, 412-416

Shrivastava B., Jain K.K., Kalra A., Kuhad R.C., 2014. Bioprocessing of wheat straw into nutritionally rich and digested cattle feed. Sci. Rep. 4,6360, https://doi.org/10.1038/srep06360
Shrivastava B., Nandal P., Sharma A., Jain K.K., Khasa Y.P., Das T.K., Mani V., Kewalramani N.J., Kundu S.S., Kuhad R.C., 2012. Solid state bioconversion of wheat straw into digestible and nutritive ruminant feed by Ganoderma sp rckk02. Bioresour. Technol. 107, 347-351, https://doi.org/10.1016/j.biortech.2011.12.096

Siu R.G.H., 1951. Microbial Decomposition of Cellulose. Reinhold Publishing Corp. New York, NY (USA)

Theodorou M.K., Williams B.A., Dhanoa M.S., McAllan A.B., France J., 1994. A simple gas production method using a pressure transducer to determine the fermentation kinetics of ruminant feeds. Anim. Feed Sci. Technol. 48, 185-197, https://doi. org/10.1016/0377-8401(94)90171-6

Van Soest P.J., Robertson J.B., Lewis B.A., 1991. Methods for dietary fiber, neutral detergent fiber and non-starch polysaccharides in relation to animal nutrition. J. Dairy Sci. 74, 3583-3597, https://doi.org/10.3168/jds.S0022-0302(91)78551-2

Watanabe H., Tokuda G., 2010. Cellulolytic systems in insects. Annu. Rev. Entomol. 55, 609-632, https://doi.org/10.1146/annurevento-112408-085319 